\title{
Science and Technology Changing Education: The Application of New Media Technology in University Museums
}

\author{
Ke Zhao ${ }^{1, a, *}$ \\ ${ }^{1}$ Electronic Science and Technology Museum, University of Electronic Science and Technology of China, \\ Chengdu 611731, China. \\ a zhaoke@uestc.edu.cn
}

Keywords: New Media Technology; University Museums; Education.

\begin{abstract}
With the rise of new media technologies, museums are playing a vital role in the three missions - education, research and community engagement. As an important part of the museum, the university museum not only has profound academic background but also is the forefront position of the museum for innovative education. It should seize the key opportunity for the development of new media technology and innovatively make use of new media technology integrated with sound, light, electricity and the Internet in exhibition. New media technologies like WeChat and virtual reality technology are used to attract more visitors, enhance the visit experience and promote the level of educational result for audience.
\end{abstract}

\section{Introduction}

The definition of new media by Wired in the United States is "Everyone's Communication to all" [1]. It is a new type of network information carrier that relies on computer technology and has the feature of communication and interaction, including websites, mobile applications, virtual technology, video games, human-computer interaction, etc., with strong interactivity, a wide range of coverage, timeliness and convenience [2]. New media technologies are often compared with the "old media" such as television, radio and paper media, and have characteristics of digitization, networking and diversification. They change the inefficiency in single transmission and non-interactive dilemma of the traditional paper and break the space-time limit and broaden the channel for vast amounts of information. Due to the development of mobile Internet technology, new media has completely changed the form of information dissemination, and even changed lifestyle of people.

The rise of new media has effectively broadened the channels and resources of the education, research and collection of university museums, and provided them with a more diversified and open platform for education, exhibition and publicity as well as a review of their perspectives. Therefore, university museums should seize the tide of development of new media, raise its ideological understanding, seize the opportunity in the information era, go forward with the times and occupy the main position of communication and education in the new era.

\section{The application of new media technology in the museum}

The new media technology offers more possibilities to the museum's education, exhibition and collection functions, and makes use of the existing science as an aid to make the design of museums, public education and popularization more flexible, diversified and digital to meet the cognitive needs of new generation. Many well-known social and university museums at home and abroad actively adapt to the Internet environment, continuing to tap the implementation of new media space. And we use the official website, WeChat official account, QR code and multimedia technology to create digital/virtual museum, AR/VR museum and such new exhibition forms [3].

Due to the limitations of museum design and the protection of the ancient buildings, most of time, the audience can only watch the exhibits through the showcase or fence from a long distance. Because 
of the limitation of light, location and distance, the exhibits can't be seen totally, which makes it hard to get intuitive information from the visiting process. However, if we apply the new media technology to exhibiting and education of museums, it can effectively reduce the effect of external factors and close the invisible distance between museums and visitors [3].

For example, the Beijing Imperial Palace Museum combines the VR technology with voice navigation to create a large series of virtual reality works entitled "Prince's Palace," including a 3D tour experience. All these make the ancient buildings and collections more charming and more attractive. So, the fact that the audience could have an untrammeled visit in the virtual situation can achieve such an experience effect which make them learn deeply and shorten the distance between the exhibits and the audience at the same time.

In addition, the U.S. News Museum, co-founded by Hewlett-Packard Company and the museum itself, is exploring the development of new media technology. In the new media exhibition hall, there are four sections that consist of self-talkers, choosing reading, production release and interactive games. They are equipped with eight HP Slate 500 tablet systems, HP Vantage Point multi-touch LCD video wall, photon engine system and sports tracking technology to complete the audience's experience like selfie dubbing, reading, making news forums and somatosensory game. And these technologies could enhance the audience's feeling of immersion and participation in the museum and provide the visitors a platform to perform autonomously in the venues [4].

\section{The attempt of new media technology in university museums}

The university museum has a strong backing of education, with social education resources and academic research resources. The exhibits have characteristics of distinctive features, diverse education and open thinking and so on. These advantages also determine the university museum possesses space and resources to apply new media technology.

As the first comprehensive electronic science and technology museum in China, Electronic Science and Technology Museum relies on the advanced electronic technology and makes use of the existing scientific and technological achievements, including the inverse influence to the exhibition, education and research from new media technology. This museum creates the public website and WeChat official account named "Electronic Science and Technology Museum". These website and account regularly release the latest exhibition information, public events and collection updates. The museum also pays attention to the timeliness and participation required by the mass media, opening interactive feedback columns, building the "Audience - Museum" interactive feedback platform, using the powerful engine of the Internet anytime and anywhere. This useful method breaks the old style of exhibition and education. What is more, this official platform keeps the authority and accuracy of the information giving to audience, bring them an immersive education through the debris route of transmission.

Secondly, AR technology, which is hot at this stage, has become one of the most important means for university science museums to exhibit and teach through the new media technology. Most university museums attach more importance to the research and investment in this field. The Electronic Science and Technology Museum gives full play to the great potential of AR technology in exhibition and actively create the "whole process AR museum" based on this technology [5]. Before the visit, the "whole process AR museum" system helps audience find the museum by using AR navigation and touch virtual collections in advance on the brochures. During the visit, the system helps audience to superimpose virtual information on the real world and the real collections. Through the system, the past running state of apparatus is shown on it so that the audience could "touch" the collection's past and gain a better understanding of the collection. After the visit, the audience can also take away the postcards of collection from the museum. After leaving the museum, scanning the postcards by AR technology, the visitors are able to continue to aftertaste the collection in all dimensions and bring the entire museum home. The use of "whole process AR Museum" system has enabled many electronic technology products retiring from the stage of history or unrecoverable to recreate the operational scenarios and return to public view. With an educational purpose by 
enhancing exhibition fun and science, the AR technology provides an educational process to visitors so that they can feel the charm and interest of electronic science and technology in the subtle experience. It also makes them realize that the science museum should use the existing scientific and technological achievements to feed back the innovation of the museum functions. At the same time, immersive education is also provided to the audience through such conversational and experiential way.

The initial attempt of new media technology in many university museums at home and abroad played a very strong role in promoting the publicity and education in museum. Due to the giant space to play, it is worth all university museums to create innovation, which requires university museum staff to pay more attention to ideological understanding and work involvement. They need to grasp the ever-changing trend of science and technology in the new media era and incorporate scientific and technological achievements into the functions of the museum.

\section{The future of new media technology applied in university museum}

Relying on its own characteristics of digitization, interactivity and timeliness, the new media technology has formed a powerful force that can't be ignored in the publicity and education of university museums to some extent. However, in the future, university museum staff should focuse on the sustainable effect of new media technologies to the university museums [1]. As an auxiliary means of interaction, promotion, education and research in cognition and positioning, the new media technology is also the future trend of the university museums in the application of internet technology.

Museums has changed its role from a leading actor to supporting actor with the purpose to focuse on the audience. Different from our generation called "the network immigrants", "after 90" and "after 00" generations have become "the network aborigines" in the new media era. They are highly sensitive to the emerging technologies represented by new media and the Internet. At the same time, these "Aborigines" are also the main audiences of service and education for university museums. Therefore, we should pay more attention to the visit needs and visit feelings of "new media aborigines" nowadays. We need to make the new media technology, which is familiar and attractive to them, as a carrier of exhibition and education so that we can fulfill the relative curiosity within its own knowledge and age range and forms an "edutainment network" education for a new generation of youth. After reaching a certain stage, the university museum should also change from a leading guiding role to a coordinating role and build a platform for this generation of young people who are "new media aboriginals", so that they can themselves lead and create display and learn independently.

Furthermore, we should be aware of technicalism, avoid abuse of technology. University museums should use new media technology for exhibition, education and publicity from the point of setting up technical means to serve the goal of educating people and avoid abuse of new media technologies. According to the collection and the audience need, the extent of new media technology use should be adjusted to achieve the rational allocation of technical resources, display and seamless integration of new media technologies. If excessive use of scientific and technological aids is used, the essense of educational activities itself will be obscured, resulting in a simple "show of dazzling skills" that will not reach the ideological education of audiences and will also lose the educational functions of university museums.

Indeed, it is necessary to construct logical value of university museums and highlight the narrative core of museums. University museums should realize its own logical value in exhibitions, publicity, education, collection research and other explicit and implicit functions. It is also advisable to establish the dialogues between exhibits and audiences and build the exhibition-guidance model through organic combination of traditional media and new media. Audiences will see the spirit of the history events, focus on the inner core of the collections without being overshadowed by the bright and fresh appearance of new media technology. Accordingly, they will have an impressive impression and a profound sense of visiting experience. 


\section{Conclusions}

In short, as a product of the information age, new media technology occupies the main position of social cognition with extremely rapid momentum, accumulates a large number of audiences and exerts a profound influence on the university museums at the forefront of cultural education. It is an important task for university museums to innovate and educate young generation by tapping into the implementation space of new media technology in universities and enhancing the functions of education, research and collection.

\section{References}

[1] Zhuokai Xu. Exploration of new media technology in the museum of technology applications and development of design, J. Science and Technology Outlook, 2017, 27 (18).

[2] Xinyang Liu. Digital technology interpretation history display: the application of new media technology in museum exhibition display, J. Journal of Design Art, 2012, 02 (2): 37-42.

[3] Dongran Peng. New Media in the Museum of Applied Research, J. Beauty and the Times of City, 2017, (7).

[4] Ling Miao, Dongmei Zhou. The Experiment and Inspiration of New Media Hall in American News Museum: Also on the Application of New Media Technology in News Communication in Social Media Era, J. Chinese Journalist, 2016, (5).

[5] Ke Zhao. To Exert the Educational Function of University Science Museum and Improve the Comprehensive Quality of College Students: A Case Study of Electronic Science and Technology Museum, J. West China Quality Education, 2017,3 (18): 1. 